\title{
Raman and infrared spectra, conformations and $a b$ initio calculations of 3-methoxymethylene-2,4-pentanedione
}

\author{
Anton Gatial ${ }^{a}$, Viktor Milata ${ }^{b}$, Nadežda Prónayovác, \\ Klaus Herzogd, Reiner Salzer ${ }^{d}$ \\ ${ }^{a}$ Institute of Physical Chemistry and Chemical Physics, Faculty of Chemical and Food Technology, \\ Slovak University of Technology, Radlinského 9, SK-812 37 Bratislava, Slovakia \\ ${ }^{b}$ Institute of Organic Chemistry, Catalysis and Petrochemistry, Faculty of Chemical and Food Technology, \\ Slovak University of Technology, Radlinského 9, SK-812 37 Bratislava, Slovakia \\ ${ }^{c}$ Department of NMR Spectroscopy and Mass Spectroscopy, Faculty of Chemical and Food Technology, \\ Slovak University of Technology, Radlinského 9, SK-812 37 Bratislava, Slovakia \\ ${ }^{d}$ Institute of Analytical Chemistry, Technical University Dresden, 01062 Dresden, Germany \\ anton.gatial@stuba.sk
}

\begin{abstract}
The IR (4000-400 $\left.\mathrm{cm}^{-1}\right)$ and Raman (4000-50 $\left.\mathrm{cm}^{-1}\right)$ spectra of 3-methoxymethylene-2,4-pentanedione $\left[\mathrm{H}_{3} \mathrm{C}-\mathrm{O}-\mathrm{CH}=\mathrm{C}\left(\mathrm{COCH}_{3}\right)_{2}\right]$ as a liquid and solutes in various solvents of different polarity have been recorded at ambient temperature. Additional IR and Raman spectra were obtained for amorphous and crystalline solid state at low temperature. The vibrational spectra revealed that the compound exists at least in two dominant conformers of different polarity and that the conformer present in the solid phase is less polar. NMR spectra in various solvents at different temperatures were also obtained.

The compound can exist in several conformers due to the rotation around $\mathrm{O}-\mathrm{C}=$ and both $=\mathrm{C}-\mathrm{C}$ bonds with planar or nonplanar arrangements of heavy atoms. Ab initio MP2 and DFT calculations using a wide scale of basis sets were carried out. According to these calculations six conformational structures of the eight theoretically possible conformational structures with the methoxy group oriented as anti or syn and carbonyl groups oriented as $Z$ or $E$ towards the $\mathrm{C}=\mathrm{C}$ double bond were obtained at potential energy surface. It has been shown that the conformers with the $E$ orientations of both acetyl groups are not the stable ones. The calculated $a b$ initio MP2 and DFT energies of all found conformers in vacuum suggest the most stable $Z E a$ conformer where $Z$ and $E$ regard to the trans and cis acetyl groups, respectively and $a$ denotes the orientation of the methoxy group. The EZa conformer was calculated as the second most stable one with the energy by at least $10 \mathrm{~kJ} \mathrm{~mol}^{-1}$ higher. Corrections of the relative energies of single conformers obtained in vacuum on the polar surroundings were done by including the solvent effect into the calculations using IEF Polarizable Continuum Model.

Assignments of the vibrational spectra for the studied compound were made with the aid of normal coordinate calculations employing scaled $a b$ initio force field. The scaled $a b$ initio frequencies as well as calculated energies indicate that $Z E a$ is the conformer present in the solid phase.
\end{abstract}

Keywords: Raman and Infrared spectra, NMR spectra, conformational analysis, alkoxymethylenes and diacetylethenes, ab initio MP2 and B3LYP calculations.

\section{Introduction}

Alkoxymethylenes of general formula $\mathrm{R}-\mathrm{O}-\mathrm{CH}=$ $=\mathrm{CXY}$, where $\mathrm{R}$ are alkyl or (hetero)aryl electrondonor groups and $\mathrm{X}$ and $\mathrm{Y}$ are electron-withdrawing groups, represent simple push-pull compounds. As relatively easy accessible and highly reactive compounds they are very important in a number of syntheses. Their reactions with aliphatic, aromatic or heteroatomic amines give the corresponding $\mathrm{N}$-(un) substituted aminomethylene compounds which are used as starting materials for many pharmaceuticals, dyes, polymers and other products (Cook, 1969; Dyke, 1973; Albrecht, 1977; Bouzard, 1990).

The studied 3-methoxymethylene-2,4-pentanedione $\left[\mathrm{H}_{3} \mathrm{C}-\mathrm{O}-\mathrm{CH}=\mathrm{C}\left(\mathrm{COCH}_{3}\right)_{2}\right](\mathrm{MMP})$ has $\mathrm{R}=\mathrm{CH}_{3}$ and $\mathrm{X}=\mathrm{Y}=\mathrm{COCH}_{3}$. The first conformational pos- sibility of MMP is given by the rotation around the $\mathrm{O}-\mathrm{C}=$ single bond with the methyl group in the anti or syn orientation towards the $\mathrm{C}=\mathrm{C}$ double bond. The simplest model for such conformational possibility is methyl vinyl ether as a parent compound for MMP and its conformers are at Fig. 1. Methyl vinyl ether has been widely studied by vibrational spectroscopy (Owen, 1964; Ignatyev, 1981; Cadioli, 1982), electron diffraction (Owen, 1970, Samdal, 1975, Pyckhout, 1983), microwave spectroscopy (Cahill, 1968) and infrared matrix isolation spectroscopy (Beech, 1985). These studies have shown that methyl vinyl ether in the fluid phases exists in two conformers: the less polar and planar syn conformer is more stable and the less stable one is the more polar and probably nonplanar anti conformer. The enthalpy difference between the conformers was 
found to be $4.8 \pm 1.0 \mathrm{~kJ} \mathrm{~mol}^{-1}$ in the gas phase and $2.8 \pm 0.8 \mathrm{~kJ} \mathrm{~mol}^{-1}$ in 1,1,2-trichloroethane (Owen, 1964). In the liquid phase the enthalpy differences of $6.0 \pm 0.7 \mathrm{~kJ} \mathrm{~mol}^{-1}$ and $6.2 \pm 0.5 \mathrm{~kJ} \mathrm{~mol}^{-1}$ were obtained, respectively (Cadioli, 1982; Sakakibara, 1976). From the matrix isolation study the enthalpy difference of $6.6 \pm 0.4 \mathrm{~kJ} \mathrm{~mol}^{-1}$ was measured (Beech, 1985).

The similar conclusion has been done from the conformational study of 2-methoxypropene $\left[\mathrm{H}_{3} \mathrm{C}-\mathrm{O}-\mathrm{C}\left(\mathrm{CH}_{3}\right)=\mathrm{CH}_{2}\right]$ by vibrational spectroscopy (Diallo, 1981; Gallinella, 1983). The spectra revealed the presence of two conformers with the enthalpy difference of $3.6 \mathrm{~kJ} \mathrm{~mol}^{-1}$ in the liquid state and it has been found from the vapour phase spectra that the more stable conformer has a planar structure and a syn configuration of heavy atoms.

On the other side the substitution of both ending ethylene hydrogens by some electron-withdrawing groups support the anti orientation of the methoxy group as it has been shown by vibrational and conformational studies of methoxymethylene-propanedinitrile $\left[\mathrm{H}_{3} \mathrm{C}-\mathrm{O}-\mathrm{CH}=\mathrm{C}(\mathrm{CN})_{2}\right]$ and 1-methoxyethylidene-propanedinitrile $\left[\mathrm{H}_{3} \mathrm{C}-\mathrm{O}-\mathrm{C}\left(\mathrm{CH}_{3}\right)=\mathrm{C}(\mathrm{CN})_{2}\right]$ (Gatial, 1997, Gatial, 2004).

The additional conformational possibility for MMP is given by the rotation of both acetyl groups around the $=\mathrm{C}-\mathrm{C}$ single bond. The simplest compound demonstrating the conformational possibility of the vinyl and acetyl groups is methyl vinyl ketone $\mathrm{H}_{2} \mathrm{C}=\mathrm{CH}-\mathrm{COCH}_{3}$ (Bowles, 1969, Durig, 1981, de Smedt, 1989). For its two conformers all heavy atoms are located in a plane and are denoted as the s-trans $(E)$ and s-cis $(Z)$ with respect to the orientation of the two $\mathrm{C}=\mathrm{C}$ and $\mathrm{C}=\mathrm{O}$ double bonds (Fig. 2). The s-trans conformer is more stable by $2.4 \pm 0.2 \mathrm{~kJ} \mathrm{~mol}^{-1}$ (Bowles, 1969) and $2.1 \mathrm{~kJ} \mathrm{~mol}^{-1}$ (Durig, 1981) in the gas and liquid phases, respectively, and by $1.9 \pm 0.1 \mathrm{~kJ} \mathrm{~mol}^{-1}$ in the $\mathrm{CS}_{2}$ solution (de Smedt, 1989).

The conformational possibilities of MMP are given by the rotation of both acetyl groups and the stable conformers can have the orientation of the carbonyl oxygen towards or away from the $\mathrm{C}=\mathrm{C}$ double bond marked as $Z$ or $E$ orientations. Therefore, MMP can have theoretically four orientations of both acetyl groups $Z Z, Z E, E Z$ and $E E$ where the first letter expresses the orientation of the trans acetyl group and the second one the orientation of the cis acetyl group. Additionally the third letters $a$ or $s$ will denote the orientation of methoxy group. Therefore, MMP can theoretically exist as $Z Z a, Z E a, E Z a, E E a$, $Z Z s, Z E s, E Z s$ and EEs conformers. The conformations of both acetyl groups strongly depend on the possibility to create stabilizing intramolecular hydrogen bond between the electron-donor group, e.g. amino group $\mathrm{H}_{2} \mathrm{~N}$ - (Gróf, 2007) or alkylamino group R-NH- (Gatial, 2015) and carbonyl of the cis acetyl group. The conformers with such bond belong to the most stable ones. On the other side for compounds without the possibility to create such an intramolecular hydrogen bond, e.g. compounds with dialkylamino group $\mathrm{R}^{1} \mathrm{R}^{2} \mathrm{~N}$ - (Gatial, 2011) or alkoxy group $\mathrm{R}-\mathrm{O}$ - (Gatial, 1999), also other conformers can belong to the most stable ones.

Planarity favoured by the conjugation of studied alkoxymethylenes can often be difficult to achieved for steric reasons due to the substituent size of both the $\mathrm{X}, \mathrm{Y}$ groups or the size of the $\mathrm{R}-\mathrm{O}$ - alkoxy group. Therefore for MMP one or both carbonyls may lie out of ethene plane, or alternatively the whole molecule may twist along the axis of the carbon double bond. Due to the steric effects a nonplanar gauche conformation of acetyl group can result from the rotation around the $=\mathrm{C}-\mathrm{C}$ single bond from either the s-trans or s-cis positions. The three double bonds of MMP represent a cross-conjugated system. In hydrocarbon frameworks the simplest cross-conjugated molecule is 3-methylene-1,4-pentanediene (Almenningen, 1988) where electron diffraction, in agreement with the ab initio calculations, revealed that the most stable conformer has two double bonds coplanar with the s-trans arrangement and the third one is twisted from s-cis positions by 40 degrees.

\section{Experimental and computational details}

The purity and identity of the compound were checked by mass and NMR spectroscopy. Mid-IR

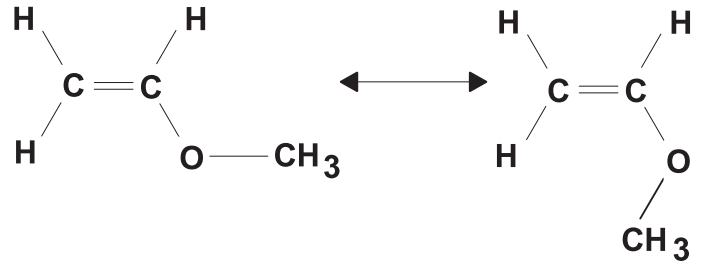

anti

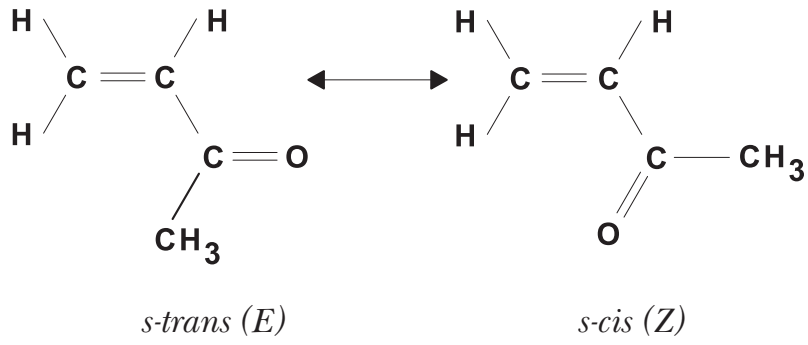

Fig. 2. Conformers of methyl vinyl ketone. 
spectra in the $4000-400 \mathrm{~cm}^{-1}$ region were recorded on Bruker model IFS 88 and on Nicolet model NEXUS 470 FT-IR spectrometers at room temperature. The solution IR spectra in chloroform and acetonitrile were measured in a Specac cell equipped with $\mathrm{KBr}$ windows. Cryostats cooled with liquid nitrogen and with windows of CsI and polyethylene were used in solid IR measurements. Raman spectra in the $4000-50 \mathrm{~cm}^{-1}$ region were measured on Bruker RFS 100 Raman spectrometer with $\mathrm{Nd}^{3+}$ : YAG laser at the wavelength of $1064 \mathrm{~nm}$. The Raman spectra of the solutions were obtained at room temperature. A liquid capillary of $3 \mathrm{~mm}$ inner diameter surrounded by a Dewar and cooled by a flow of cold nitrogen gas was used for Raman solid state measurements.

NMR spectroscopy was performed in the solutions of dimethylsulfoxide (DMSO) and chloroform $\left(\mathrm{CDCl}_{3}\right)$ in order to confirm the identity of the sample. ${ }^{1} \mathrm{H}$ NMR and ${ }^{13} \mathrm{C}$ NMR spectra were recorded at room temperature with both Varian VXR-300 and INOVA 600 spectrometers. The ${ }^{13} \mathrm{C}$ and ${ }^{1} \mathrm{H}$ NMR spectra in DMSO at room temperature and in chloroform and acetone, cooled to -60 and $-80{ }^{\circ} \mathrm{C}$, respectively, were run with a Varian VXR-300 spectrometer and no evidences of separate spectra due to restricted $\mathrm{O}-\mathrm{C}=$ or $=\mathrm{C}-\mathrm{C}$ rotations were obtained.

Ab initio MP2 (Møller, 1934) and DFT B3LYP (Becke, 1988; Lee et al., 1988; Becke, 1993) computations were performed using the Gaussian03 (Frisch et al., 2003) and Gaussian09 (Frisch et al., 2009) program packages. Standard basis sets $6-31 G^{* *}, 6-311 G^{* *}$, 6-311++G**, cc-pVDZ, aug-cc-pVDZ and cc-pVTZ were used for both methods. Solvent effects in the solvents of different polarity were approximated by Integral Equation Formalism Polarizable Continuum Model (IEF PCM) (Cossi, 1996; Mennucci, 1997) and a full conformational analysis of the MMP was performed. A vibrational analysis was used to confirm that the optimal geometry corresponds to the energy minimum (no imaginary vibrations) and to obtain the vibrational spectra.

\section{Results and discussion}

\section{Quantum-chemical calculations}

In order to understand the conformational behavior of MMP and to interpret the experimental results we have supported our study by theoretical calculations. The numbering and structure of the studied compound is depicted in Fig. 3. In the first step we have tried to find all stable conformers from the eight theoretically possible ZEa, ZEs, ZZa, ZZs, EZa, EZs, EE $a$ and EEs ones. Table 1 and Table 2 summarize the calculated MP2 and DFT B3LYP relative energies of MMP conformers as well as their dipole moments for an isolated molecule (in vacuum) in several basis sets. The calculated energies for all methods and basis sets show that the most stable conformer is $Z E a$.

According to these calculations all other found conformers have much higher energy in vacuum and their appearance in a liquid phase at room temperature seems not probable. However on the other side the calculated dipole moments of the found conformers have a broad range and therefore the appearance of the next possible conformers in polar solutions can be expected. Some calculated geometrical parameters at the ab initio MP2 level in $6-311++\mathrm{G}^{* *}$ basis set are collected in Table 3 .

The relative energies of single conformers obtained in vacuum were corrected by including solvent effect into the calculations using IEF Polarizable Continuum Model (PCM) at ab initio MP2 levels in $6-311++\mathrm{G}^{* *}$ and cc-pVTZ basis sets. The energy differences between the conformers of MMP are collected in Tables $4 \mathrm{a}$ and $4 \mathrm{~b}$ and depicted in

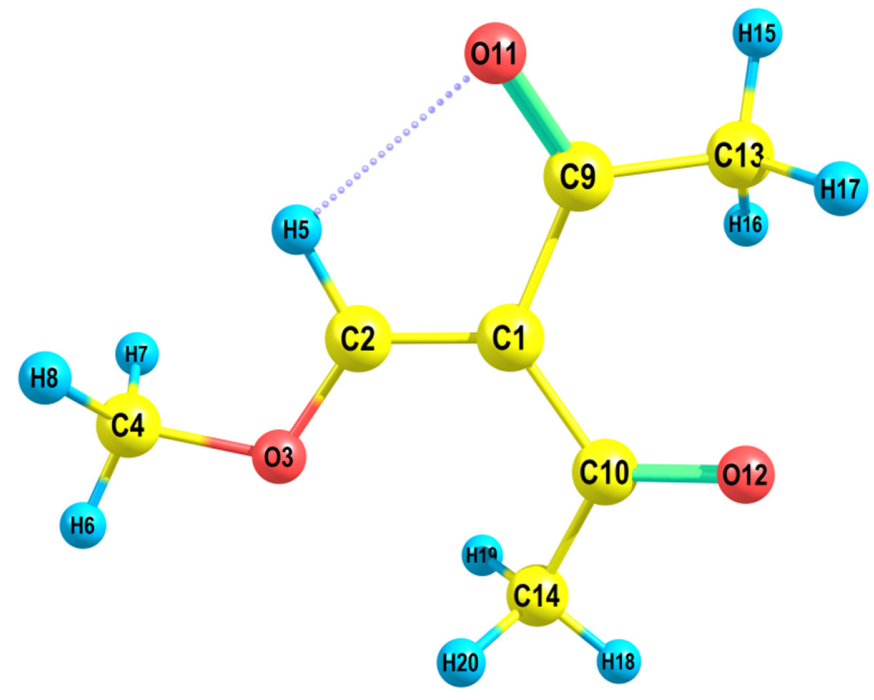

Fig. 3. Structure and numbering of atoms in MMP for $Z E a$ conformer. 
Tab. 1. Calculated MP2 relative energies including ZPE correction $\left(\mathrm{kJ} \mathrm{mol}^{-1}\right)$ of MMP stable conformers in different basis sets in vacuum. Calculated dipole moments (in Debye) are in parentheses.

\begin{tabular}{ccccccc}
\hline \multirow{2}{*}{ Conformer } & \multicolumn{7}{c}{ MP2 } \\
\cline { 2 - 7 } & $6-31 \mathrm{G}^{* *}$ & $6-311 \mathrm{G}^{* *}$ & $6-311++\mathrm{G}^{* *}$ & cc-pVDZ & aug-cc-pVDZ & cc-pVTZ \\
\hline ZEa & $0.00(4.65)$ & $0.00(4.61)$ & $0.00(4.98)$ & $0.00(4.50)$ & $0.00(4.95)$ & $0.00(4.74)$ \\
$Z E s$ & $22.98(3.11)$ & $20.99(3.00)$ & $18.42(3.28)$ & $\mathrm{a}$ & $\mathrm{a}$ & $\mathrm{a}$ \\
$Z Z a$ & $20.34(1.47)$ & $18.55(1.57)$ & $14.45(1.63)$ & $21.72(1.41)$ & $15.82(1.76)$ & $18.07(1.44)$ \\
$Z Z s$ & $22.67(2.79)$ & $21.06(2.69)$ & $16.89(2.58)$ & $23.51(2.67)$ & $13.97(2.92)$ & $19.42(2.69)$ \\
$E Z a$ & $14.34(5.68)$ & $12.47(5.66)$ & $7.84(5.93)$ & $16.12(5.21)$ & $8.14(6.11)$ & $10.57(5.78)$ \\
$E Z s$ & $14.93(3.44)$ & $14.40(3.34)$ & $10.91(3.62)$ & $15.83(3.36)$ & $6.58(3.88)$ & $11.38(3.69)$ \\
$E E a$ & $\mathrm{a}$ & $\mathrm{a}$ & $\mathrm{a}$ & $\mathrm{a}$ & $\mathrm{a}$ & $\mathrm{a}$ \\
EEs & $\mathrm{a}$ & $\mathrm{a}$ & $\mathrm{a}$ & $\mathrm{a}$ & $\mathrm{a}$ & $\mathrm{a}$ \\
\hline
\end{tabular}

a - conformer not found.

Tab. 2. Calculated DFT B3LYP relative energies including ZPE correction $\left(\mathrm{kJ} \mathrm{mol}^{-1}\right)$ of MMP stable conformers in different basis sets in vacuum. Calculated dipole moments (in Debye) are in parentheses.

\begin{tabular}{cccrcrc}
\hline \multirow{2}{*}{ Conformer } & \multicolumn{7}{c}{ B3LYP } \\
\cline { 2 - 7 } Z & $6-31 \mathrm{G}^{* *}$ & $6-311 \mathrm{G}^{* *}$ & $6-311++\mathrm{G}^{* *}$ & \multicolumn{1}{c}{ cc-pVDZ } & aug-cc-pVDZ & cc-pVTZ \\
\hline ZEs & $0.00(4.96)$ & $0.00(5.02)$ & $0.00(5.22)$ & $0.00(4.87)$ & $0.00(5.15)$ & $0.00(5.02)$ \\
$Z Z a$ & $30.41(3.59)$ & $30.33(3.59)$ & $27.15(3.76)$ & $32.81(3.51)$ & $\mathrm{a}$ & $\mathrm{a}$ \\
$Z Z s$ & $22.74(1.37)$ & $21.86(1.61)$ & $17.11(1.90)$ & $24.83(1.37)$ & $16.52(1.58)$ & $17.98(1.58)$ \\
$E Z a$ & $28.09(2.68)$ & $27.96(2.71)$ & $24.86(2.84)$ & $30.91(2.61)$ & $23.79(2.79)$ & $26.23(2.69)$ \\
$E Z s$ & $18.44(5.60)$ & $17.30(5.85)$ & $12.33(6.25)$ & $19.40(5.42)$ & $11.06(6.14)$ & $12.15(5.91)$ \\
$E E a$ & $20.60(3.44)$ & $20.56(3.56)$ & $17.25(3.79)$ & $22.23(3.36)$ & $16.34(3.75)$ & $18.16(3.63)$ \\
$E E s$ & $\mathrm{a}$ & $\mathrm{a}$ & $\mathrm{a}$ & $\mathrm{a}$ & $\mathrm{a}$ & $\mathrm{a}$ \\
\hline
\end{tabular}

$\mathrm{a}$ - conformer not found.

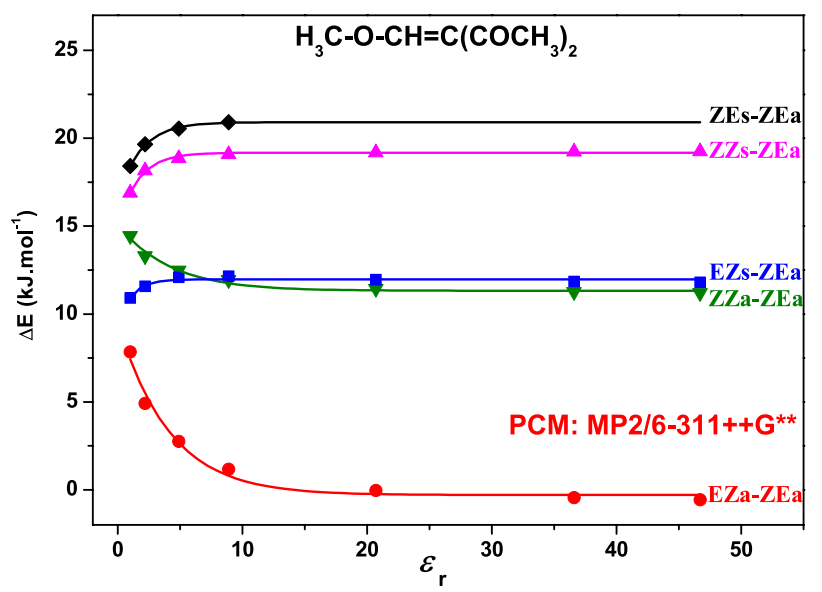

Fig. 4. Energy difference between isomers and conformers of MMP as a function of relative permittivity of surroundings calculated by IEF PCM model at $a b$ initio MP2 level with $6-311++\mathrm{G}^{* *}$ basis set.

Figs. 4 and 5. From these results we can see that $Z E a$ conformer remains the most stable one also in very polar surroundings. As the second most stable

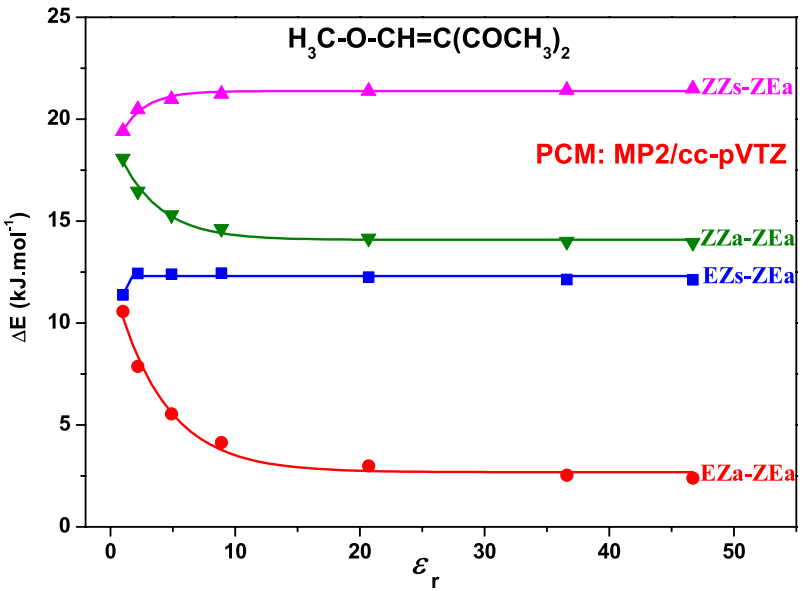

Fig. 5. Energy difference between isomers and conformers of MMP as a function of relative permittivity of surroundings calculated by IEF PCM model at $a b$ initio MP2 level with cc-pVTZ basis set.

conformer remains $E Z a$ one but its energy drops down from the values of $8-10 \mathrm{~kJ} \mathrm{~mol}^{-1}$ for vacuum to the value of about $2-0 \mathrm{~kJ} \mathrm{~mol}^{-1}$ in very polar sur- 
Tab. 3. Some geometric parameters of stable MMP conformers calculated at ab initio MP2 level with $6-311++G^{* *}$ basis set in vacuum.

\begin{tabular}{|c|c|c|c|c|c|c|}
\hline Coordinate $^{\mathrm{a}}$ & $Z E a$ & ZEs & $Z Z a$ & $Z Z s$ & $E Z a$ & $E Z s$ \\
\hline \multicolumn{7}{|l|}{ Bonds $(\AA)$} \\
\hline $\mathrm{C}_{1}=\mathrm{C}_{2}$ & 1.360 & 1.358 & 1.356 & 1.362 & 1.354 & 1.364 \\
\hline $\mathrm{C}_{2}-\mathrm{O}_{3}$ & 1.339 & 1.342 & 1.336 & 1.334 & 1.343 & 1.334 \\
\hline $\mathrm{O}_{3}-\mathrm{C}_{4}$ & 1.434 & 1.433 & 1.431 & 1.430 & 1.429 & 1.432 \\
\hline $\mathrm{C}_{1}-\mathrm{C}_{9}$ & 1.506 & 1.505 & 1.491 & 1.501 & 1.477 & 1.486 \\
\hline $\mathrm{C}_{1}-\mathrm{C}_{10}$ & 1.489 & 1.501 & 1.500 & 1.497 & 1.512 & 1.503 \\
\hline $\mathrm{C}_{9}=\mathrm{O}_{11}$ & 1.226 & 1.223 & 1.226 & 1.224 & 1.229 & 1.229 \\
\hline $\mathrm{C}_{10}=\mathrm{O}_{12}$ & 1.227 & 1.223 & 1.222 & 1.225 & 1.219 & 1.224 \\
\hline $\mathrm{C}_{9}-\mathrm{C}_{13}$ & 1.512 & 1.514 & 1.517 & 1.517 & 1.519 & 1.519 \\
\hline $\mathrm{C}_{10}-\mathrm{C}_{14}$ & 1.514 & 1.516 & 1.521 & 1.517 & 1.508 & 1.513 \\
\hline \multicolumn{7}{|l|}{ Angles $\left(^{\circ}\right)$} \\
\hline $\mathrm{C}_{1}=\mathrm{C}_{2}-\mathrm{O}_{3}$ & 124.9 & 130.1 & 123.1 & 131.9 & 121.7 & 131.7 \\
\hline $\mathrm{C}_{1}=\mathrm{C}_{2}-\mathrm{H}_{5}$ & 118.6 & 118.5 & 119.4 & 117.7 & 122.3 & 119.4 \\
\hline $\mathrm{C}_{2}-\mathrm{O}_{3}-\mathrm{C}_{4}$ & 114.2 & 118.4 & 114.6 & 119.4 & 114.6 & 120.1 \\
\hline $\mathrm{C}_{2}=\mathrm{C}_{1}-\mathrm{C}_{9}$ & 114.1 & 115.8 & 116.9 & 114.3 & 122.1 & 118.8 \\
\hline $\mathrm{C}_{2}=\mathrm{C}_{1}-\mathrm{C}_{10}$ & 124.8 & 125.7 & 120.6 & 127.4 & 119.9 & 125.6 \\
\hline $\mathrm{C}_{1}-\mathrm{C}_{9}=\mathrm{O}_{11}$ & 120.6 & 121.8 & 122.1 & 122.2 & 119.8 & 119.5 \\
\hline $\mathrm{C}_{1}-\mathrm{C}_{10}=\mathrm{O}_{12}$ & 119.8 & 122.0 & 121.5 & 122.4 & 120.4 & 120.4 \\
\hline $\mathrm{C}_{1}-\mathrm{C}_{9}-\mathrm{C}_{13}$ & 118.5 & 116.8 & 116.9 & 116.3 & 119.4 & 120.2 \\
\hline $\mathrm{C}_{1}-\mathrm{C}_{10}-\mathrm{C}_{14}$ & 119.4 & 115.8 & 117.7 & 116.2 & 116.0 & 118.1 \\
\hline \multicolumn{7}{|l|}{ Dihedral angles $\left({ }^{\circ}\right)$} \\
\hline $\mathrm{C}_{1}=\mathrm{C}_{2}-\mathrm{O}_{3}-\mathrm{C}_{4}$ & -174.8 & 20.3 & -172.8 & 7.7 & -164.4 & 10.5 \\
\hline $\mathrm{O}_{3}-\mathrm{C}_{2}=\mathrm{C}_{1}-\mathrm{C}_{9}$ & -178.9 & -174.3 & -178.6 & -178.8 & -176.3 & -175.7 \\
\hline $\mathrm{O}_{3}-\mathrm{C}_{2}=\mathrm{C}_{1}-\mathrm{C}_{10}$ & 0.8 & 8.9 & 3.1 & 7.1 & 4.5 & 10.1 \\
\hline $\mathrm{H}_{5}-\mathrm{C}_{2}=\mathrm{C}_{1}-\mathrm{C}_{9}$ & -1.1 & 4.3 & -1.1 & -0.7 & 1.3 & 2 \\
\hline $\mathrm{H}_{5}-\mathrm{C}_{2}=\mathrm{C}_{1}-\mathrm{C}_{10}$ & 178.6 & -172.4 & -179.4 & -174.7 & -177.9 & -171.9 \\
\hline $\mathrm{C}_{2}=\mathrm{C}_{1}-\mathrm{C}_{9}=\mathrm{O}_{11}$ & 22.3 & -0.7 & 12.9 & 27.4 & 180.0 & -174.1 \\
\hline $\mathrm{C}_{2}=\mathrm{C}_{1}-\mathrm{C}_{10}=\mathrm{O}_{12}$ & -158.9 & -115.5 & 53.9 & 57.2 & 68.7 & 51 \\
\hline $\mathrm{C}_{2}=\mathrm{C}_{1}-\mathrm{C}_{9}-\mathrm{C}_{13}$ & -155.1 & 179.2 & -165.4 & -147.8 & -0.7 & 5 \\
\hline $\mathrm{C}_{2}=\mathrm{C}_{1}-\mathrm{C}_{10}-\mathrm{C}_{14}$ & 20.9 & 70.3 & -124.7 & -121.6 & -110.4 & -129 . \\
\hline
\end{tabular}

${ }^{a}$ Numbering of atoms according to Fig. 3 .

roundings in DMSO. Therefore in polar solutions the presence of the $E Z a$ conformer is possible.

Due to problems with finding some conformers with the $E E$ orientation of both acetyl groups we have studied the dependence of the potential energy for the transition between $Z E a$ and $E E a$ conformers by the rotation of the trans acetyl group for several fixed dihedral angles of the cis acetyl group. This dependence is depicted at Fig. 6. It is clear that $E E$ orientation of both acetyl groups has much higher energy and it is evident that this dependence for the cis acetyl group being in the plane of ethylene group (dihedral angle $180.0^{\circ}$ ) has no minimum. For fixed dihedral angles of the cis acetyl group outside of the plane of ethylene group the potential energy dependence has otherwise a minimum on the opposite side of the plane of ethylene group but after the optimization of all geometrical parameters always one of acetyl groups turned into the $Z$ position. A similar situation occurs when the trans acetyl group is fixed and the cis acetyl group rotates (Fig. 7).

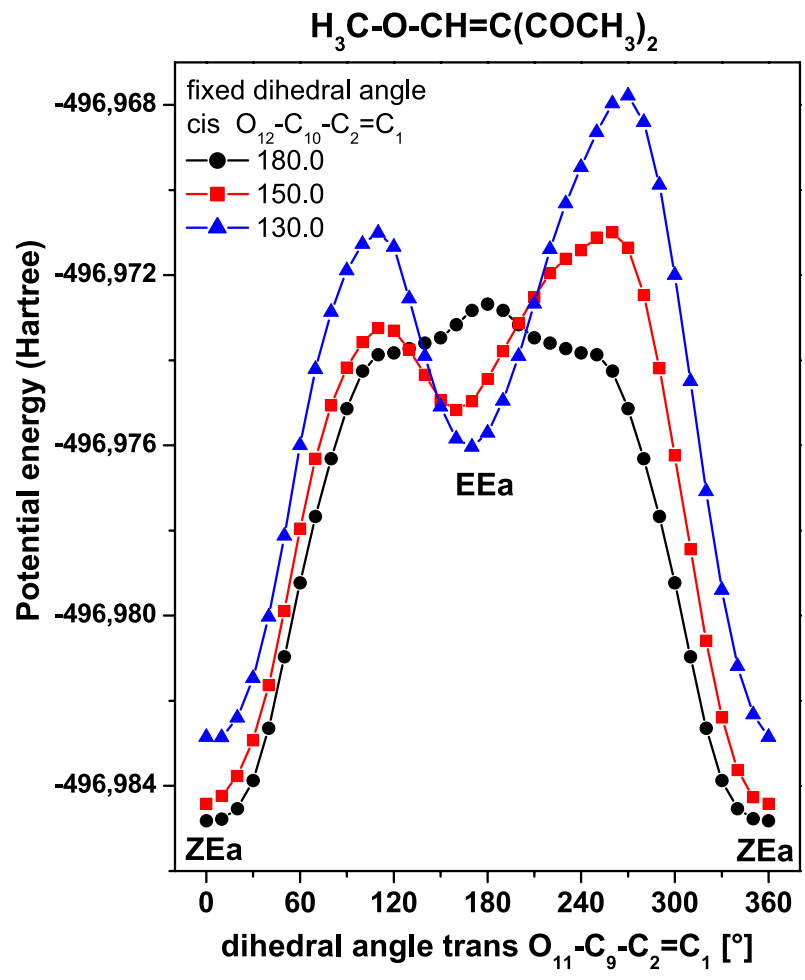

Fig. 6. Dependence of potential energy of MMP on the dihedral angle of trans acetyl group for fixed dihedral angle of cis acetyl group at ab initio MP2 level with cc-pVDZ basis set.

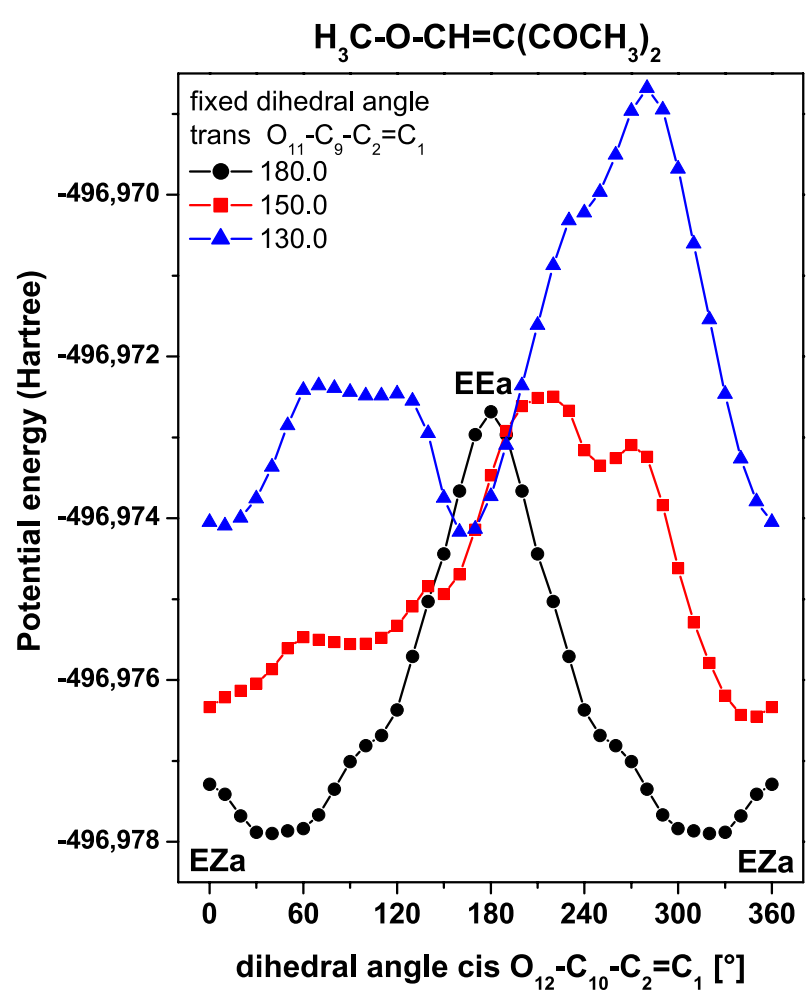

Fig. 7. Dependence of potential energy of MMP on the dihedral angle of cis acetyl group for fixed dihedral angle of trans acetyl group at ab initio MP2 level with cc-pVDZ basis set. 
Tab. 4a. Calculated MP2 relative energies in 6-311++ $\mathrm{G}^{* *}$ basis set $\left(\mathrm{kJ} \mathrm{mol}^{-1}\right)$ for MMP conformers in the gas phase $\left(\varepsilon_{\mathrm{r}}=1\right)$, in $\mathrm{CCl}_{4}\left(\varepsilon_{\mathrm{r}}=2.2\right)$, in chloroform $\left(\varepsilon_{\mathrm{r}}=4.7\right)$, in dichloromethane $\left(\varepsilon_{\mathrm{r}}=8.9\right)$, in acetone $\left(\varepsilon_{\mathrm{r}}=20.5\right)$, in acetonitrile $\left(\varepsilon_{\mathrm{r}}=35.7\right)$ and in DMSO $\left(\varepsilon_{\mathrm{r}}=46.8\right)$ solutions according to IEF PCM solvent model.

\begin{tabular}{lcccccccc}
\hline \multirow{2}{*}{ Conformer } & \multicolumn{7}{c}{ MP2/6-311++G** } \\
\cline { 2 - 8 } & $\varepsilon_{\mathrm{r}}=1.0$ & $\varepsilon_{\mathrm{r}}=2.2$ & $\varepsilon_{\mathrm{r}}=4.7$ & $\varepsilon_{\mathrm{r}}=8.9$ & $\varepsilon_{\mathrm{r}}=20.5$ & $\varepsilon_{\mathrm{r}}=35.7$ & $\varepsilon_{\mathrm{r}}=46.8$ \\
\hline$Z E a$ & 0.00 & 0.00 & 0.00 & 0.00 & 0.00 & 0.00 & 0.00 \\
$Z E s$ & 18.42 & 19.66 & 20.55 & 20.92 & $\mathrm{a}$ & $\mathrm{a}$ & $\mathrm{a}$ \\
$Z Z a$ & 14.45 & 13.30 & 12.48 & 11.94 & 11.44 & 11.26 & 11.20 \\
$Z Z s$ & 16.89 & 18.17 & 18.86 & 19.09 & 19.19 & 19.24 & 19.25 \\
$E Z a$ & 7.85 & 4.92 & 2.76 & 1.17 & -0.04 & -0.44 & -0.57 \\
$E Z s$ & 10.91 & 11.58 & 12.09 & 12.16 & 11.96 & 11.85 & 11.80 \\
$E E a$ & $\mathrm{a}$ & $\mathrm{a}$ & $\mathrm{a}$ & $\mathrm{a}$ & $\mathrm{a}$ & $\mathrm{a}$ & $\mathrm{a}$ \\
$E E s$ & $\mathrm{a}$ & $\mathrm{a}$ & $\mathrm{a}$ & $\mathrm{a}$ & $\mathrm{a}$ & $\mathrm{a}$ & $\mathrm{a}$ \\
\hline
\end{tabular}

a - conformer not found.

Tab. 4b. Calculated MP2 relative energies in cc-pVTZ basis set $\left(\mathrm{kJ} \mathrm{mol}^{-1}\right)$ for MMP conformers in the gas phase $\left(\varepsilon_{\mathrm{r}}=1\right)$, in $\mathrm{CCl}_{4}\left(\varepsilon_{\mathrm{r}}=2.2\right)$, in chloroform $\left(\varepsilon_{\mathrm{r}}=4.7\right)$, in dichloromethane $\left(\varepsilon_{\mathrm{r}}=8.9\right)$, in acetone $\left(\varepsilon_{\mathrm{r}}=20.5\right)$, in acetonitrile $\left(\varepsilon_{\mathrm{r}}=35.7\right)$ and in DMSO $\left(\varepsilon_{\mathrm{r}}=46.8\right)$ solutions according to IEF PCM solvent model.

\begin{tabular}{lccccccc}
\hline \multirow{2}{*}{ Conformer } & \multicolumn{7}{c}{ cc-pVTZ } \\
\cline { 2 - 8 } ZEa & $\varepsilon_{\mathrm{r}}=1.0$ & $\varepsilon_{\mathrm{r}}=2.2$ & $\varepsilon_{\mathrm{r}}=4.7$ & $\varepsilon_{\mathrm{r}}=8.9$ & $\varepsilon_{\mathrm{r}}=20.5$ & $\varepsilon_{\mathrm{r}}=35.7$ & $\varepsilon_{\mathrm{r}}=46.8$ \\
$Z E s$ & 0.00 & 0.00 & 0.00 & 0.00 & 0.00 & 0.00 & 0.00 \\
$Z Z a$ & $\mathrm{a}$ & $\mathrm{a}$ & $\mathrm{a}$ & $\mathrm{a}$ & $\mathrm{a}$ & $\mathrm{a}$ & $\mathrm{a}$ \\
$Z Z s$ & 18.07 & 16.46 & 15.30 & 14.62 & 14.15 & 14.00 & 13.95 \\
$E Z a$ & 19.42 & 20.48 & 20.98 & 21.24 & 21.38 & 21.43 & 21.50 \\
$E Z s$ & 10.57 & 7.88 & 5.55 & 4.14 & 3.00 & 2.54 & 2.39 \\
$E E a$ & 11.38 & 12.43 & 12.40 & 12.45 & 12.25 & 12.14 & 12.12 \\
$E E s$ & $\mathrm{a}$ & $\mathrm{a}$ & $\mathrm{a}$ & $\mathrm{a}$ & $\mathrm{a}$ & $\mathrm{a}$ & $\mathrm{a}$ \\
\hline
\end{tabular}

a - conformer not found.

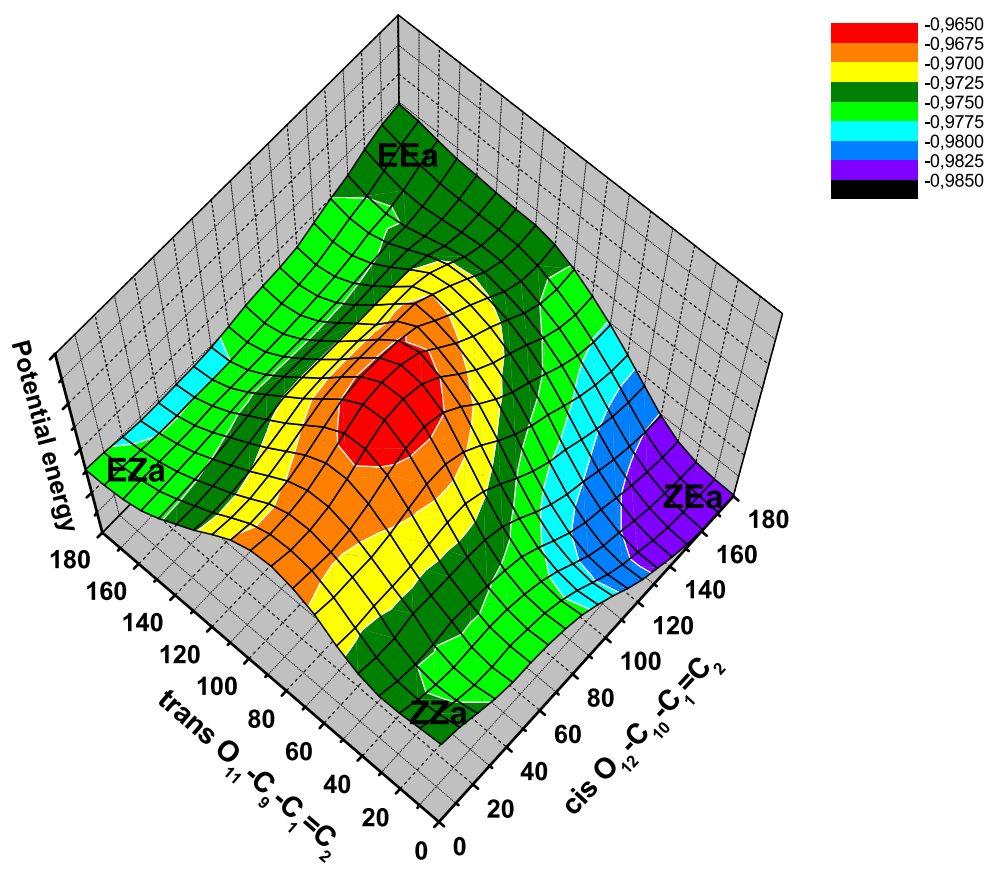

Fig. 8. Dependence of potential energy of MMP (in Hartree, related to the $-497,0000$ Hartree value) on relevant dihedral angles (in degrees) at ab initio MP2 level with cc-pVDZ basis set. 
Therefore we can conclude that the $E E$ orientation of both acetyl groups is not stable probably due to the charge repulsion of both carbonyl oxygens which disfavours the $E E$ arrangement of both acetyl groups. To test such conclusion we have calculated the potential energy surface (PES) for fixed dihedral angles of both acetyl groups of MMP with the anti orientation of the methoxy group and results are depicted at Fig. 8. From the analysis of the PES we can see that the energy of the $E E$ arrangement is the highest one and that the PES has not a global minimum for such an arrangement.

\section{NMR spectra}

The ${ }^{1} \mathrm{H}$ NMR spectra of MMP in chloroform and DMSO solutions are presented in Fig. 9. The comparison of the ${ }^{13} \mathrm{C}$ NMR spectra of MMP in chloroform and DMSO solutions with the calculated NMR spectra at ab initio MP2 level with cc-pVTZ basis set using IEF PCM solvation model for the $Z E a$ and EZa conformers are shown in Fig. 10. The hydrogen and carbon experimental chemical shifts are given in Table 5. We can observe in the ${ }^{1} \mathrm{H}$ NMR spectrum the signals of two acetyl methyl groups (at 2.1-2.4 ppm), the signals of methoxy groups (at $4.0 \mathrm{ppm}$ ) and the signals of the olefinic hydrogen (at 7.6-7.7 ppm). None of the mentioned observed hydrogen signals are split to indicate the free rotation of the above groups at room temperature. The number of carbon resonances in chloroform (bottom) as well as in DMSO (top) spectrum in Fig. 10 corresponds to the presence of only one entity in both solutions. Such situation is also in the acetone solution at the temperature of $-80{ }^{\circ} \mathrm{C}$. This can imply that MMP exists in these solutions as only one conformer or that the coalescence temperature for the rotation around the $\mathrm{O}-\mathrm{C}=$ or $=\mathrm{C}-\mathrm{C}$ bonds is bellow this temperature. The middle spectrum compares the calculated resonances for $Z E a$ and EZa conformers at MP2 level with cc-pVTZ basis set using IEF PCM solvation model with chloroform as a solvent.

Experimental resonances of $\mathrm{C}_{1}$ and $\mathrm{C}_{2}$ in the ethylenic group and of $\mathrm{C}_{4}$ in the methoxy group are very similar in chloroform as well as in DMSO solution. On the other side the experimental $\mathrm{C}_{9}$ and $\mathrm{C}_{10}$ carbonyl resonances and $\mathrm{C}_{13}$ and $\mathrm{C}_{14}$ methyl carbon resonances for both acetyl groups are more separated in DMSO solution. The calculated differences of chemical shifts of $\mathrm{C}_{9}$ and $\mathrm{C}_{10}$ carbonyl resonances and $\mathrm{C}_{13}$ and $\mathrm{C}_{14}$ methyl carbons resonances in chloroform solution for $E Z a$ conformer are higher in comparison with the same ones for $Z E a$ conformer (the middle spectrum at Fig. 10). This can indicate that the abundance of the more polar EZa conformer in the DMSO solution is higher than in the chloroform solution.

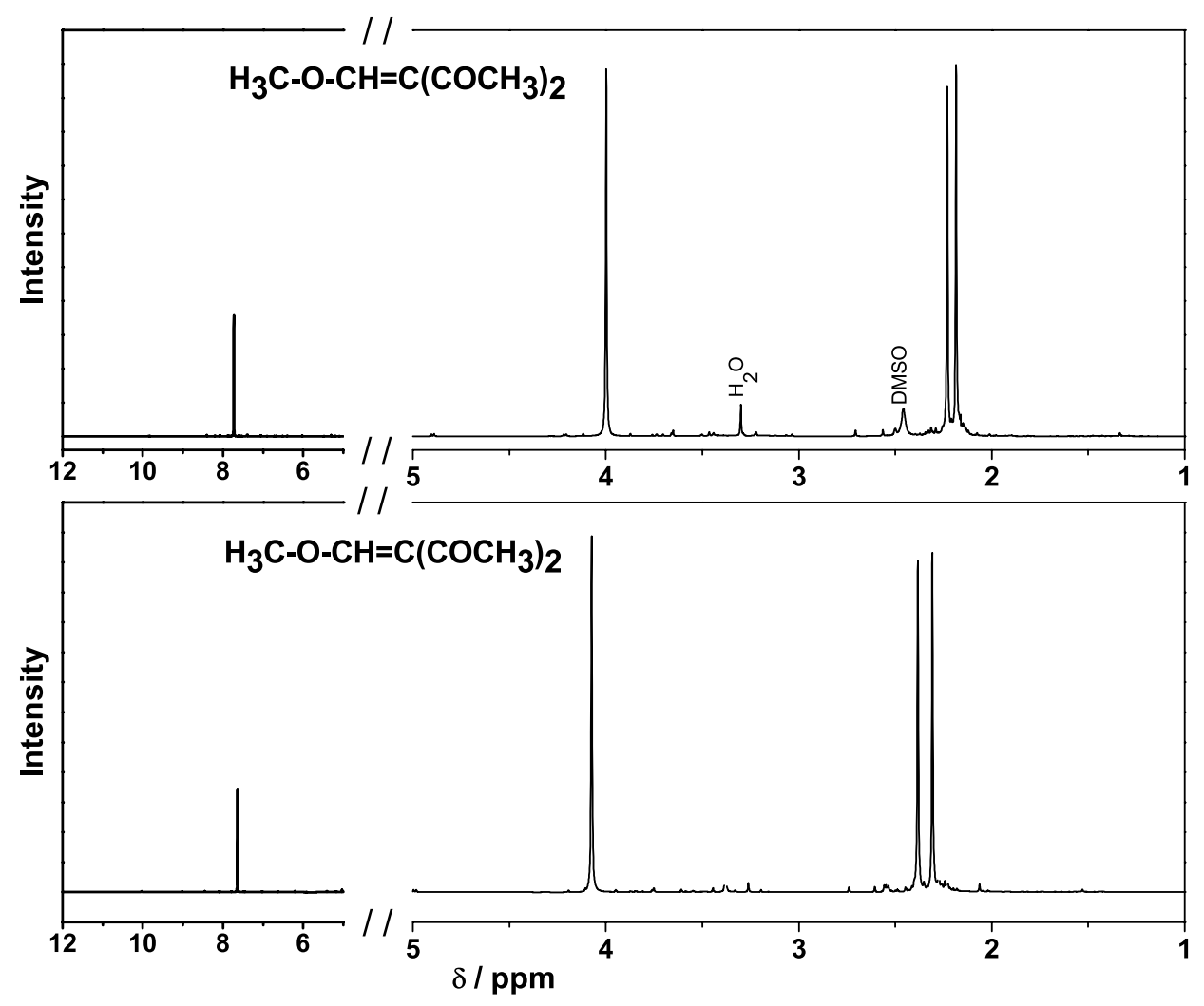

Fig. 9. ${ }^{1} \mathrm{H}$ NMR spectra of MMP in $\mathrm{CDCl}_{3}$ (bottom) and in DMSO (top) at room temperature. 


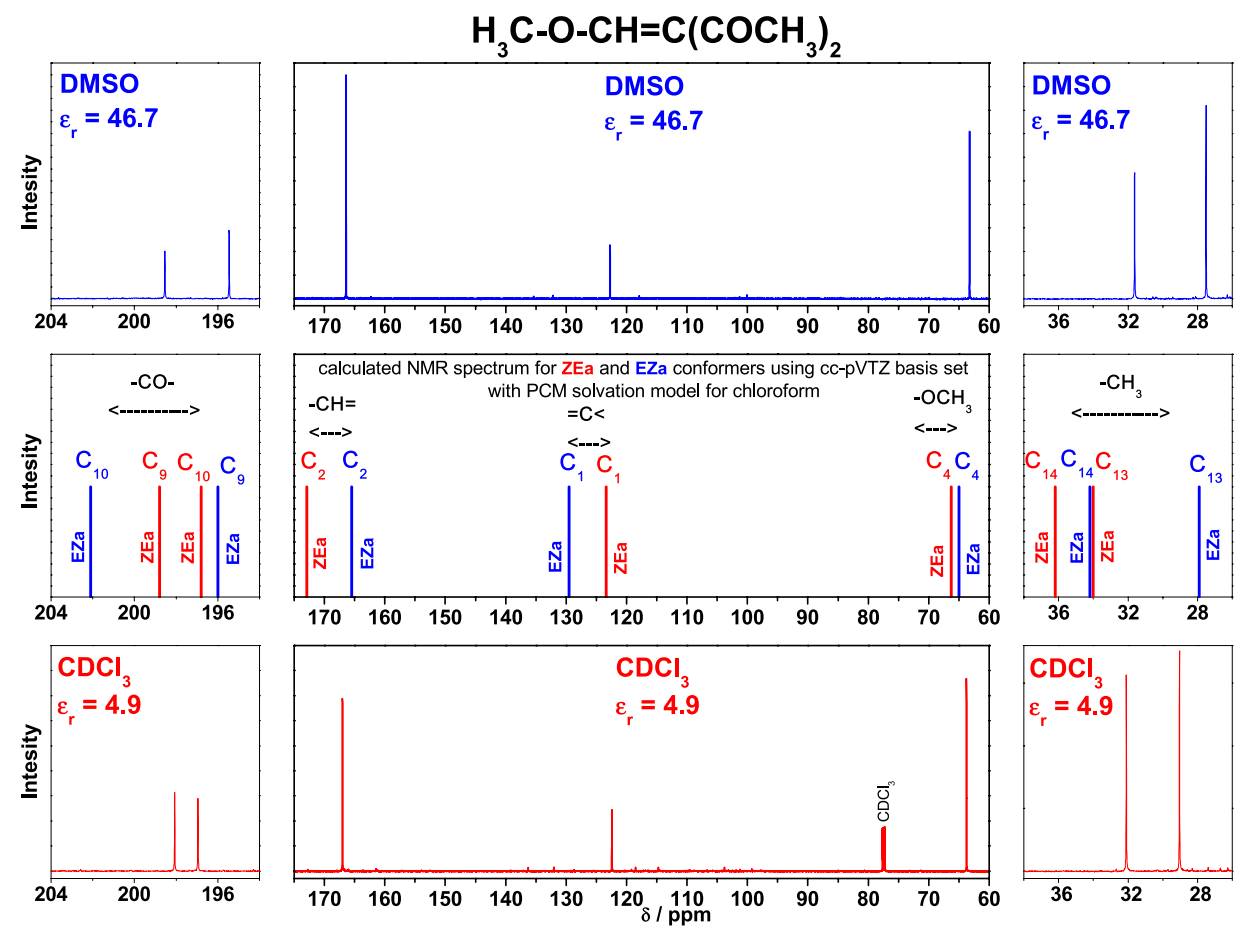

Fig. 10. ${ }^{13} \mathrm{C}$ NMR spectra of MMP in $\mathrm{CDCl}_{3}$ (bottom) and in DMSO (top) at room temperature. In the middle the calculated spectra for both $Z E a$ and $E Z a$ confomers are depicted.

Tab. 5. Measured NMR spectral data of 3-methoxymethylene-2,4-pentanedione (MMP).

\begin{tabular}{lrr}
\hline \multirow{2}{*}{ Carbon spectra } & \multicolumn{2}{c}{ Chemical shifts $(\mathrm{ppm})$} \\
\cline { 2 - 3 }$>\mathrm{C}=$ & 122.74 & $\mathrm{CDCl}_{3}$ \\
\hline $\mathrm{CH}=$ & 166.41 & 122.44 \\
$\mathrm{CH}_{3}$ & 63.25 & 167.01 \\
$\mathrm{C}=\mathrm{O}$ & 198.54 & 198.75 \\
$\mathrm{C}=\mathrm{O}$ & 195.45 & 196.95 \\
$\mathrm{CH}_{3}$ & 31.63 & 32.10 \\
$\mathrm{CH}_{3}$ & 27.51 & 29.04 \\
\hline $\mathrm{Hydrogen} \mathrm{spectra}$ & & \\
\hline $\mathrm{CH}_{3}$ & 2.19 & 2.31 \\
$\mathrm{CH}_{3}$ & 2.23 & 2.38 \\
$\mathrm{OCH}_{3}$ & 4.00 & 4.04 \\
$=\mathrm{C}-\mathrm{H}$ & 7.73 & 7.64 \\
\hline
\end{tabular}

\section{Vibrational spectra}

Since the sample has a small vapour pressure, only the measurements as a pure liquid and in solvents of different polarities at room temperature and in a solid phase at low temperature have been performed. The survey mid-infrared and Raman liquid and solid phase spectra of MMP are depicted in Fig. 11 and experimental frequencies are collected in $\mathrm{Ta}$ ble 6. Disappearing of several bands from IR as well as Raman liquid phase spectra in comparison with the solid phase spectra support the assumption than MMP exists in the liquid phase as a mixture of at least two conformers. The comparison of the liquid phase Raman spectra of MMP with those measured in $\mathrm{CCl}_{4}$, chloroform, dichloromethane and acetonitrile solutions in the most significant $1775-1525 \mathrm{~cm}^{-1}$ region, where the $\mathrm{C}=\mathrm{O}$ and $\mathrm{C}=\mathrm{C}$ double bond stretching vibrations can be expected, are shown in Figs. 12. These studies confirm the presence of at least two conformers with very different dipole moments in solutions of different polarity. The bands denoted with the asterisk increase their intensity in more polar solvents and disappeared in solid phase what means that less stable second conformer is more polar and that more stable less polar conformer in liquid phase is also present in the crystallized solid phase.

Experimental spectra in Figs. 13 and 14 are compared with the calculated ones for $Z E a$ and $E Z a$ conformers at MP2 level with cc-pVTZ basis set. Calculated vibrational frequencies were scaled by the scale factor of 0.96 according to [Merrick, 2007] and calculated Raman scattering activities were recalculated on the Raman scattering cross sections which are proportional to the Raman intensities. For the depicting of the calculated spectra the Lorentzian band shape with the halfwidth of $4 \mathrm{~cm}^{-1}$ for IR and Raman spectra has been used. The MP2/cc-pVTZ force field was transformed from Cartesian coordinates to a set of suitable internal coordinates and the potential energy distribution (PED) was calculated for each mode. The comparison of the calculated and observed vibration frequencies of MMP conformers and PED for $Z E a$ conformer is in Table 7. 


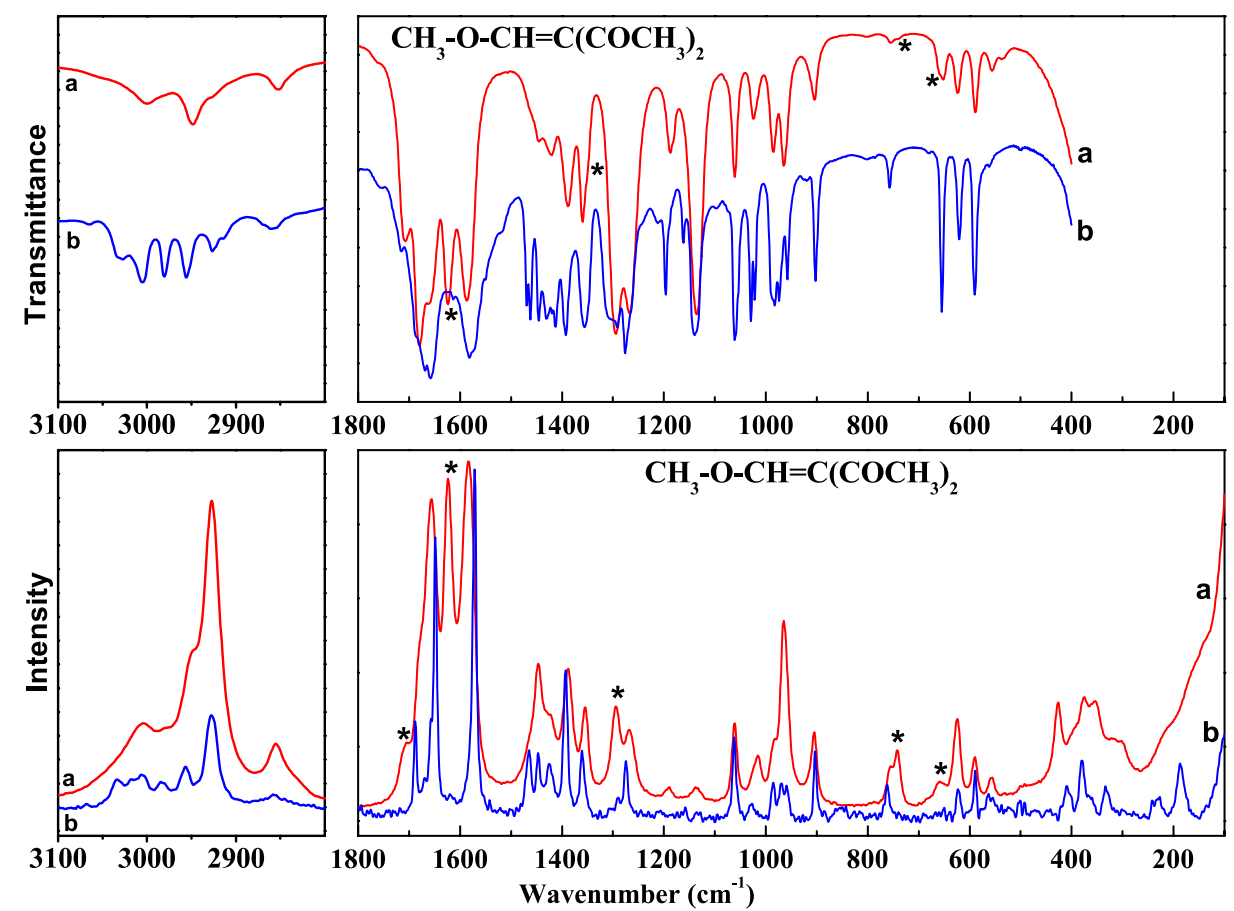

Fig. 11. IR (top) and Raman (bottom) spectra of MMP as a neat liquid (curve a) at room temperature and in the solid state (curve b). * denote bands vanishing in the solid phase.

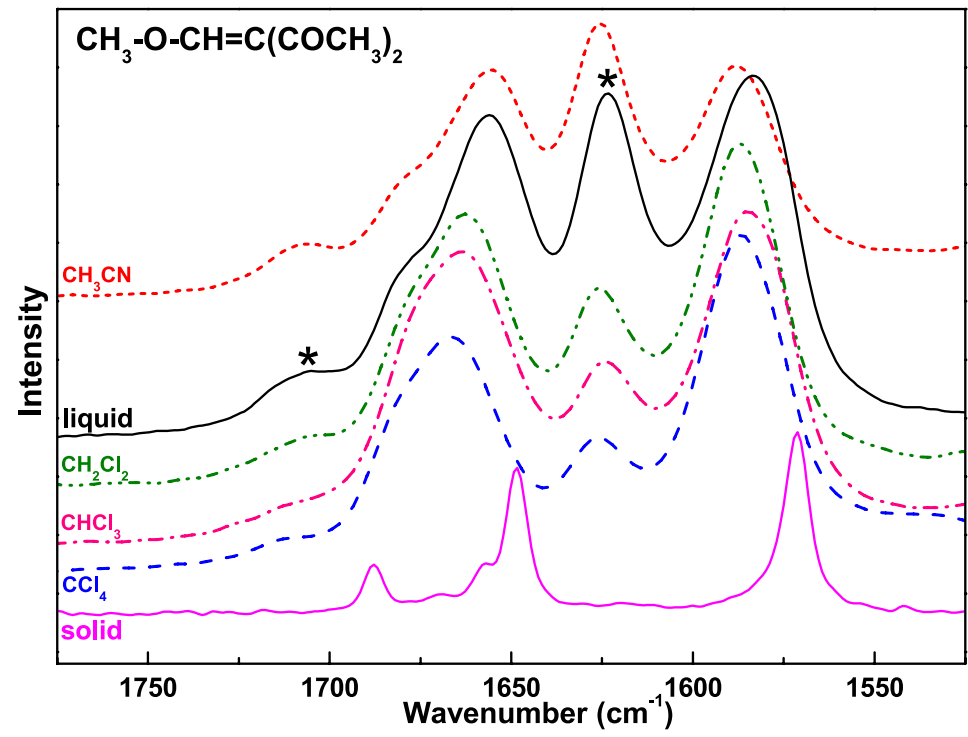

Fig. 12. Raman spectra of MMP as a neat liquid (top solid line) and in solvents of different polarity at room temperature and in the solid state (bottom solid line). * denote bands vanishing in solid phase.

Three bands above $1580 \mathrm{~cm}^{-1}$ therefore belong to the $\mathrm{C}=\mathrm{O}$ and $\mathrm{C}=\mathrm{C}$ stretching modes. The assignment of the $\mathrm{C}=\mathrm{O}$ stretching modes for $Z E a$ and $E Z a$ conformers is opposite according to the PED. Because for $Z E a$ conformer the calculated higher frequency band at $1672 \mathrm{~cm}^{-1}$ can be assigned to the $\mathrm{C}=\mathrm{O}$ stretch vibration of the trans acetyl group with the $Z$ orientation of $\mathrm{C}=\mathrm{O} / \mathrm{C}=\mathrm{C}$ bonds (55 trans $\mathrm{C}=\mathrm{O} \mathrm{s}, 11 \mathrm{C}=\mathrm{C} \mathrm{s}$ ) and the lower frequency band at $1650 \mathrm{~cm}^{-1}$ to the $\mathrm{C}=\mathrm{O}$ stretch of the cis acetyl group with the $E$ orientation of $\mathrm{C}=\mathrm{O} / \mathrm{C}=\mathrm{C}$ bonds ( 72 cis $\mathrm{C}=\mathrm{O}$ s), thus for $E Z a$ conformer the calculated higher frequency band at $1685 \mathrm{~cm}^{-1} \mathrm{can}$ be assigned to the $\mathrm{C}=\mathrm{O}$ stretch vibration of the cis acetyl group with the $Z$ orientation of $\mathrm{C}=\mathrm{O} / \mathrm{C}=\mathrm{C}$ bonds ( 80 cis $\mathrm{C}=\mathrm{O}$ s) and the lower frequency band at $1640 \mathrm{~cm}^{-1}$ to the $\mathrm{C}=\mathrm{O}$ stretch vibration of the trans acetyl group with the $E$ orientation of $\mathrm{C}=\mathrm{O}$ / $\mathrm{C}=\mathrm{C}$ bonds $(75$ trans $\mathrm{C}=\mathrm{O} \mathrm{s})$. The $\mathrm{C}=\mathrm{C}$ stretch vibrations were according to PED clearly calculated 
Tab. 6. Measured infrared and Raman spectral data ${ }^{a}$ for 3-methoxymethylene-2,4-pentanedione (MMP).

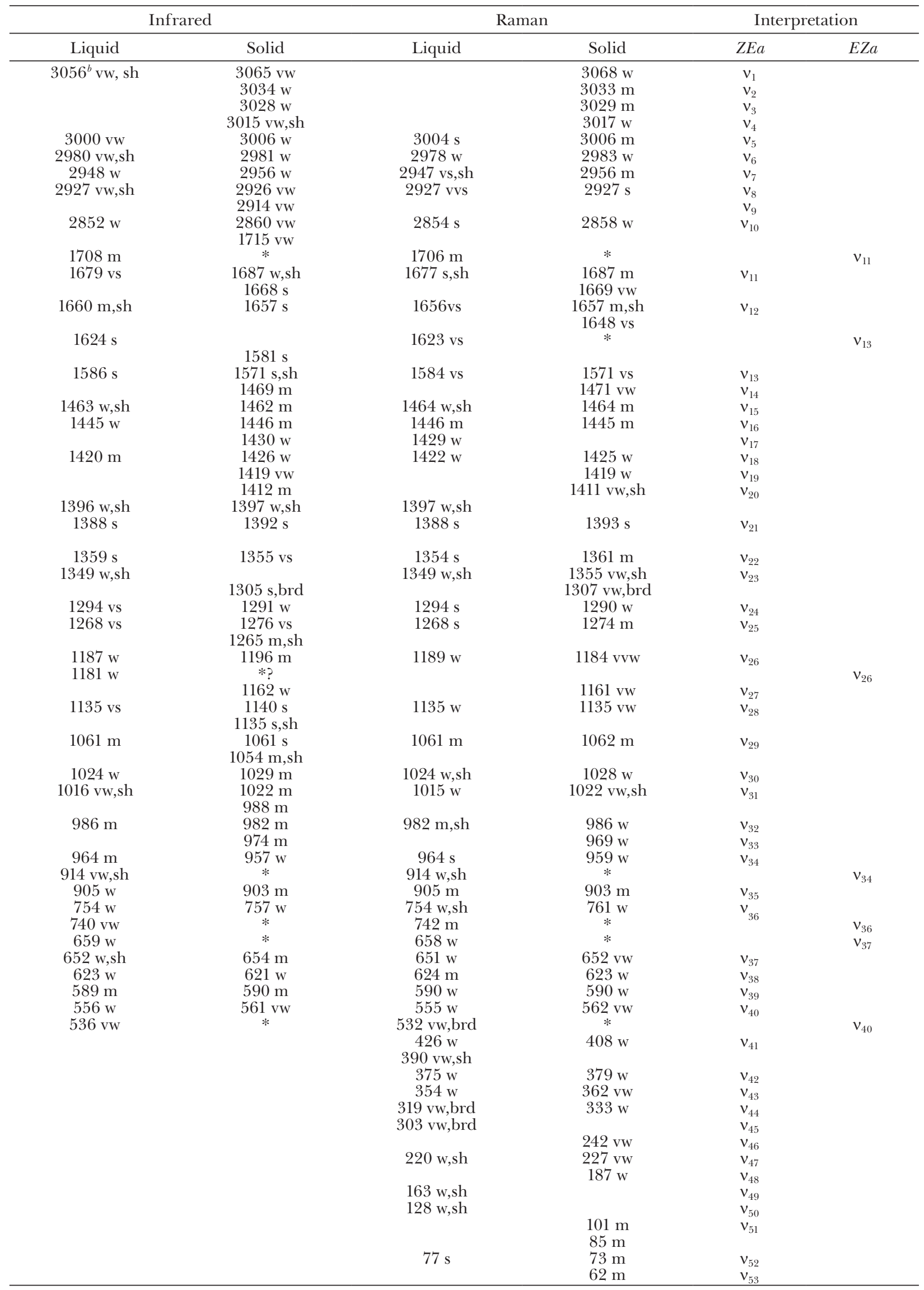

${ }^{a}$ Weak bands in 4000-3100 and 2800-1800 $\mathrm{cm}^{-1}$ regions have been omitted.

${ }^{b}$ Abbreviations: s, strong; m, medium; w, weak; v, very; sh, shoulder; brd, broad. 
Tab. 7. Comparison of calculated and observed vibration frequencies of MMP conformers at ab initio MP2 level with cc-pVTZ basis set in vacuum.

\begin{tabular}{|c|c|c|c|c|c|}
\hline \multirow[b]{2}{*}{ No. } & \multicolumn{2}{|c|}{ Calculated } & \multirow{2}{*}{$\begin{array}{l}\text { Observed } \\
\mathrm{ZEa} / \mathrm{EZa}\end{array}$} & \multirow[b]{2}{*}{ Fundamental } & \multirow[b]{2}{*}{$\operatorname{PED}(\mathrm{ZEa})^{a}$} \\
\hline & $\mathrm{ZEa}$ & EZa & & & \\
\hline$v_{1}$ & 3088 & 3086 & 3056 & $\mathrm{CH}_{3}$ asym stretch & $95(\mathrm{O}) \mathrm{CH}_{3}$ as \\
\hline$v_{2}$ & 3078 & 3076 & 3034 & $\mathrm{CH}_{3}$ asym stretch & $99(\mathrm{t}) \mathrm{CH}_{3}$ as \\
\hline$v_{3}$ & 3077 & 3076 & 3028 & $\mathrm{CH}_{3}$ asym stretch & 97 (c) $\mathrm{CH}_{3}$ as \\
\hline$v_{4}$ & 3056 & 3052 & 3015 & $\mathrm{CH}_{3}$ asym stretch & $22(\mathrm{t}) \mathrm{CH}_{3}$ as \\
\hline$v_{5}$ & 3050 & 3041 & 3000 & $=\mathrm{C}-\mathrm{H}$ stretch & $98=\mathrm{C}-\mathrm{H} \mathrm{s}$ \\
\hline$v_{6}$ & 3047 & 3040 & 2980 & $\mathrm{CH}_{3}$ asym stretch & 97 (c) $\mathrm{CH}_{3}$ as \\
\hline$v_{7}$ & 3045 & 3031 & 2948 & $\mathrm{CH}_{3}$ asym stretch & $99(\mathrm{O}) \mathrm{CH}_{3}$ as \\
\hline$v_{8}$ & 2970 & 2958 & 2927 & $\mathrm{CH}_{3}$ sym stretch & $99(\mathrm{t}) \mathrm{CH}_{3} \mathrm{ss}$ \\
\hline$v_{9}$ & 2964 & 2954 & 2914 & $\mathrm{CH}_{3}$ sym stretch & 98 (c) $\mathrm{CH}_{3}$ ss \\
\hline$v_{10}$ & 2957 & 2947 & 2852 & $\mathrm{CH}_{3}$ sym stretch & $94(\mathrm{O}) \mathrm{CH}_{3} \mathrm{ss}$ \\
\hline$v_{11}$ & 1672 & 1685 & $1677 / 1706$ & $\mathrm{C}=\mathrm{O}$ stretch & $55(\mathrm{t}) \mathrm{C}=\mathrm{O} \mathrm{s}, 11 \mathrm{C}=\mathrm{C} \mathrm{s}$ \\
\hline$v_{12}$ & 1650 & 1640 & $1656 /$ & $\mathrm{C}=\mathrm{O}$ stretch & $72(\mathrm{c}) \mathrm{C}=\mathrm{O} \mathrm{s}$ \\
\hline$v_{13}$ & 1596 & 1619 & $1584 / 1623$ & $\mathrm{C}=\mathrm{C}$ stretch & $48 \mathrm{C}=\mathrm{C} \mathrm{s}, 11=\mathrm{C}-\mathrm{H} \rho, 10=\mathrm{C}-\mathrm{O} \mathrm{s}$ \\
\hline$v_{14}$ & 1461 & 1461 & 1469 & $\mathrm{CH}_{3}$ asym bend & $87(\mathrm{O}) \mathrm{CH}_{3} \mathrm{a} \delta$ \\
\hline$v_{15}$ & 1456 & 1455 & 1463 & $\mathrm{CH}_{3}$ asym bend & $91(\mathrm{O}) \mathrm{CH}_{3} \mathrm{a} \delta$ \\
\hline$v_{16}$ & 1430 & 1437 & 1445 & $\mathrm{CH}_{3}$ asym bend & $73(\mathrm{c}) \mathrm{CH}_{3} \mathrm{a} \delta$ \\
\hline$v_{17}$ & 1429 & 1432 & 1430 & $\mathrm{CH}_{3}$ sym bend & $54(\mathrm{O}) \mathrm{CH}_{3} \mathrm{~s} \delta, 30(\mathrm{tc}) \mathrm{CH}_{3} \mathrm{a} \delta$ \\
\hline$v_{18}$ & 1426 & 1429 & 1420 & $\mathrm{CH}_{3}$ asym bend & $71(\mathrm{t}) \mathrm{CH}_{3} \mathrm{a} \delta$ \\
\hline$v_{19}$ & 1412 & 1427 & 1419 & $\mathrm{CH}_{3}$ asym bend & $79(\mathrm{c}) \mathrm{CH}_{3}$ a $\delta$ \\
\hline$v_{20}$ & 1408 & 1416 & 1412 & $\mathrm{CH}_{3}$ asym bend & $84(\mathrm{t}) \mathrm{CH}_{3} \mathrm{a} \delta$ \\
\hline$v_{21}$ & 1369 & 1367 & 1388 & $=\mathrm{C}-\mathrm{H}$ rock & $31=\mathrm{C}-\mathrm{H} \rho, 16=\mathrm{CC}_{2}$ as \\
\hline$v_{22}$ & 1341 & 1329 & 1359 & $\mathrm{CH}_{3}$ sym bend & $74(\mathrm{t}) \mathrm{CH}_{3} \mathrm{~s} \delta$ \\
\hline$v_{23}$ & 1330 & 1320 & 1349 & $\mathrm{CH}_{3}$ sym bend & 73 (c) $\mathrm{CH}_{3} \mathrm{~s} \delta$ \\
\hline$v_{24}$ & 1267 & 1276 & 1294 & $=\mathrm{C}-\mathrm{O}$ stretch & $37=\mathrm{C}-\mathrm{O} \mathrm{s}, 18=\mathrm{C}-\mathrm{H} \rho$ \\
\hline$v_{25}$ & 1253 & 1250 & 1268 & $\mathrm{CC}_{2}$ asym stretch & $30 \mathrm{CC}_{2}$ as \\
\hline$v_{26}$ & 1170 & 1168 & $1187 / 1181$ & $\mathrm{CH}_{3}$ rock & $46(\mathrm{O}) \mathrm{CH}_{3} \rho$ \\
\hline$v_{27}$ & 1140 & 1140 & 1162 & $\mathrm{CH}_{3}$ rock & $93(\mathrm{O}) \mathrm{CH}_{3} \rho$ \\
\hline$v_{28}$ & 1123 & 1132 & 1135 & $\mathrm{O}-\mathrm{C}$ stretch & $16 \mathrm{O}-\mathrm{CH}_{3} \mathrm{~s}, 15=\mathrm{C}-\mathrm{Os}$ \\
\hline$v_{29}$ & 1047 & 1048 & 1061 & $\mathrm{CH}_{3}$ rock & $18(\mathrm{c}) \mathrm{CH}_{3} \rho, 23 \mathrm{O}-\mathrm{CH}_{3} \mathrm{~s}$ \\
\hline$v_{30}$ & 1007 & 1004 & 1024 & $\mathrm{CH}_{3}$ rock & $33(\mathrm{c}) \mathrm{CH}_{3} \rho, 29(\mathrm{t}) \mathrm{CH}_{3} \rho$ \\
\hline$v_{31}$ & 1003 & 1001 & 1016 & $\mathrm{CH}_{3}$ rock & $33(\mathrm{t}) \mathrm{CH}_{3} \rho, 26$ (c) $\mathrm{CH}_{3} \rho$ \\
\hline$v_{32}$ & 981 & 963 & 986 & $\mathrm{CH}_{3}$ rock & $23(\mathrm{t}) \mathrm{CH}_{3} \rho, 14$ (c) $\mathrm{CH}_{3} \rho$ \\
\hline$v_{33}$ & 938 & 951 & 974 & $\mathrm{C}-\mathrm{CH}_{3}$ stretch & $18(\mathrm{t}) \mathrm{C}-\mathrm{CH}_{3} \mathrm{~s}, 24(\mathrm{t}) \mathrm{CH}_{3} \rho$ \\
\hline$v_{34}$ & 933 & 892 & $964 / 914$ & $=\mathrm{C}-\mathrm{H}$ wag & $67=\mathrm{C}-\mathrm{H} \omega$ \\
\hline$v_{35}$ & 892 & 878 & 905 & $\mathrm{C}-\mathrm{CH}_{3}$ stretch & $29(\mathrm{c}) \mathrm{C}-\mathrm{CH}_{3} \mathrm{~s}, 12(\mathrm{t}) \mathrm{C}-\mathrm{CH}_{3} \mathrm{~s}$, \\
\hline$v_{36}$ & 735 & 721 & $754 / 740$ & $\mathrm{CC}_{2}$ sym stretch & $18 \mathrm{CG}_{2} \mathrm{ss}, 15 \mathrm{C}=\mathrm{C}-\mathrm{O} \delta, 12 \mathrm{CG}_{2} \delta$ \\
\hline$v_{37}$ & 632 & 637 & $652 / 659$ & $\mathrm{C}=\mathrm{O}$ wag & 20 (c) $\mathrm{C}=\mathrm{O} \omega, 14$ (c) $\mathrm{C}=\mathrm{O} \omega$ \\
\hline$v_{38}$ & 597 & 603 & 623 & $\mathrm{C}=\mathrm{O}$ rock & 13 (c) $\mathrm{C}=\mathrm{O} \rho, 12$ (t) $\mathrm{C}=\mathrm{O} \rho$ \\
\hline$v_{39}$ & 568 & 532 & 589 & $\mathrm{C}=\mathrm{O}$ rock & $34(\mathrm{t}) \mathrm{C}=\mathrm{O} \rho, 23$ (c) $\mathrm{C}=\mathrm{O} \rho$ \\
\hline$v_{40}$ & 539 & 505 & $556 / 536$ & $\mathrm{C}=\mathrm{O}$ wag & $45(\mathrm{t}) \mathrm{C}=\mathrm{O} \omega, 15$ (c) $\mathrm{C}=\mathrm{O} \omega$ \\
\hline$v_{41}$ & 389 & 452 & 426 & $=\mathrm{CC}_{2}$ rock & $14=\mathrm{CC}_{2} \rho, 14 \mathrm{CO} \rho, 21=\mathrm{CC}_{2} \mathrm{~s}$ \\
\hline$v_{42}$ & 383 & 409 & 375 & $\mathrm{C}-\mathrm{C}-\mathrm{C}$ deformation & $26(\mathrm{t}) \mathrm{C}-\mathrm{C}-\mathrm{C} \delta, 14 \mathrm{C}-\mathrm{O}-\mathrm{C} \delta$ \\
\hline$v_{43}$ & 359 & 333 & 354 & $\mathrm{C}-\mathrm{C}-\mathrm{C}$ deformation & $28(\mathrm{c}) \mathrm{C}-\mathrm{C}-\mathrm{C} \delta, 20(\mathrm{t}) \mathrm{C}-\mathrm{C}-\mathrm{C} \delta$ \\
\hline$v_{44}$ & 338 & 331 & 319 & $\mathrm{C}-\mathrm{O}-\mathrm{C}$ deformation & $21 \mathrm{C}-\mathrm{O}-\mathrm{C} \delta, 15(\mathrm{t}) \mathrm{C}-\mathrm{C}-\mathrm{C} \delta$ \\
\hline$v_{45}$ & 318 & 280 & 303 & $\mathrm{C}=\mathrm{C}$ torsion & $30 \mathrm{C}=\mathrm{C} \tau, 23(\mathrm{c}) \mathrm{C}-\mathrm{C}-\mathrm{C} \delta$ \\
\hline$v_{46}$ & 223 & 186 & 242 & $=\mathrm{CC}_{2}$ deformation & $58=\mathrm{CC}_{2} \delta$ \\
\hline$v_{47}$ & 219 & 169 & 220 & $=\mathrm{CC}_{2}$ wag & $36=\mathrm{CC}_{2} \omega, 12 \mathrm{C}=\mathrm{C} \tau$ \\
\hline$v_{48}$ & 193 & 132 & 187 & $\mathrm{C}-\mathrm{CH}_{3}$ torsion & 78 (c) $\mathrm{C}-\mathrm{CH}_{3} \tau$ \\
\hline$v_{49}$ & 167 & 126 & 163 & $\mathrm{C}-\mathrm{CH}_{3}$ torsion & $68(\mathrm{t}) \mathrm{C}-\mathrm{CH}_{3} \tau$ \\
\hline$v_{50}$ & 145 & 120 & 128 & $\mathrm{C}=\mathrm{C}-\mathrm{O}$ deformation & $30 \mathrm{C}=\mathrm{C}-\mathrm{O} \delta, 33 \mathrm{CC}_{2} \rho$ \\
\hline$v_{51}$ & 129 & 114 & 101 & $\mathrm{O}-\mathrm{CH}_{3}$ torsion & $47 \mathrm{O}-\mathrm{CH}_{3} \tau, 16=\mathrm{C}-\mathrm{O} \tau, 22 \mathrm{CC}_{2} \omega$ \\
\hline$v_{52}$ & 65 & 68 & 73 & $=\mathrm{C}-\mathrm{O}$ torsion & $43=\mathrm{C}-\mathrm{O} \tau, 34 \mathrm{O}-\mathrm{CH}_{3} \tau$ \\
\hline$v_{53}$ & 53 & 49 & 62 & $\mathrm{C}-\mathrm{COCH}_{3}$ torsion & $25(\mathrm{c})=\mathrm{C}-\mathrm{C} \tau, 28(\mathrm{t})=\mathrm{C}-\mathrm{C} \tau$ \\
\hline$v_{54}$ & 31 & 32 & & $\mathrm{C}-\mathrm{COCH}_{3}$ torsion & $41(\mathrm{t})=\mathrm{C}-\mathrm{C} \tau, 29(\mathrm{c})=\mathrm{C}-\mathrm{C} \tau$ \\
\hline
\end{tabular}

${ }^{a}$ s, symmetric; a, asymmetric; (t) trans acetyl; (c) cis acetyl; s; stretch; $\delta$, deformation; $\rho$, rocking; $\omega$, wagging; $\tau$, torsion. 


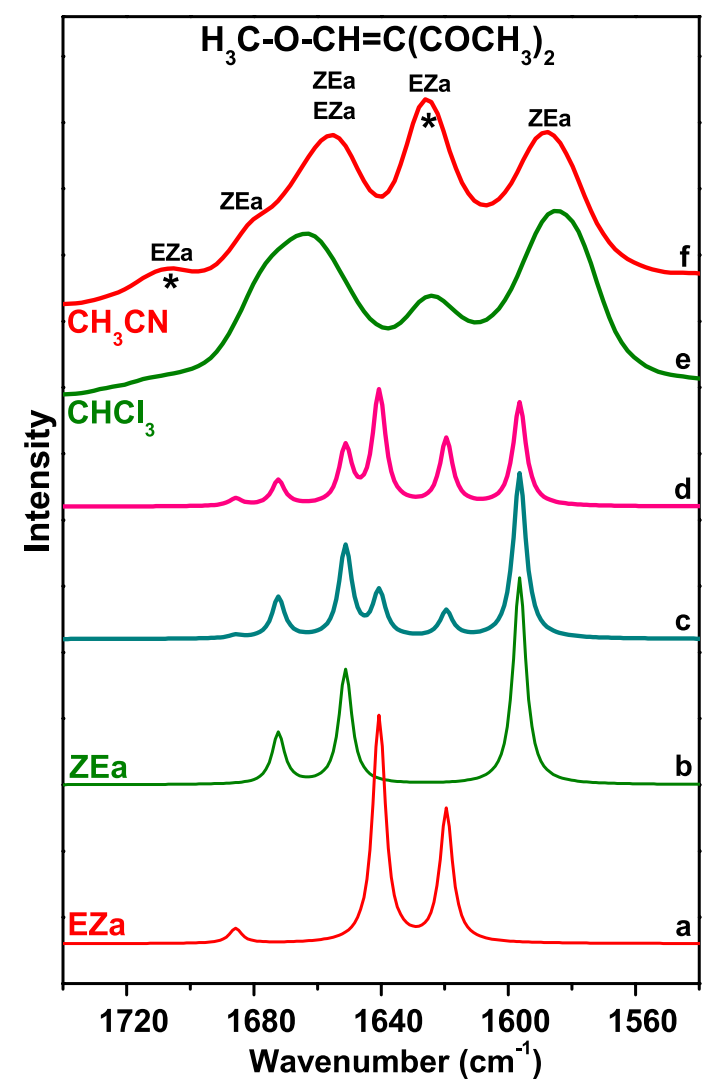

Fig. 13. Calculated Raman spectra of individual $Z E a$ and $E Z a$ MMP conformers (curves b and a, respectively) at MP2 level in cc-pVTZ basis set. Calculated Raman spectra of MMP with $80 \%$ of $Z E a$ and $20 \%$ of EZa conformers (curve c) and with $50 \%$ of $Z E a$ and $50 \%$ of EZa conformers (curve d). Curves e and $\mathrm{f}$ are experimental Raman spectra of MMP in chloroform and acetonitrile solutions at room temperature, respectively.

at $1596 \mathrm{~cm}^{-1}$ and at $1619 \mathrm{~cm}^{-1}$ for $Z E a$ and $E Z a$ conformers, respectively.

According to [Oelichmann, 1982] for the $Z$ orientation of $\mathrm{C}=\mathrm{O}$ and $\mathrm{C}=\mathrm{C}$ double bonds the difference of their vibrational band frequencies is usually over $60 \mathrm{~cm}^{-1}$ whereas for the $E$ orientation it is lower than this value. For our compound we calculated this difference of 76 and $54 \mathrm{~cm}^{-1}$ for the $Z$ and $E$ orientation of trans and cis acetyl groups, respectively, of the $Z E a$ conformer and of 66 and $21 \mathrm{~cm}^{-1}$ for the $Z$ and $E$ orientation of cis and trans acetyl groups, respectively, for the EZa conformer. The corresponding experimental differences obtained from the bands in Raman acetonitrile solution spectra are of 89 and $67 \mathrm{~cm}^{-1}$ for the $Z E a$ conformer and 80 and $29 \mathrm{~cm}^{-1}$ for the $E Z a$ conformer, respectively. Therefore in the light of the calculated wavenumbers in this region as well as in other regions we can argue for the assignment of the measured IR and Raman spectra as a mixture of $Z E a$ and $E Z a$ conformers.

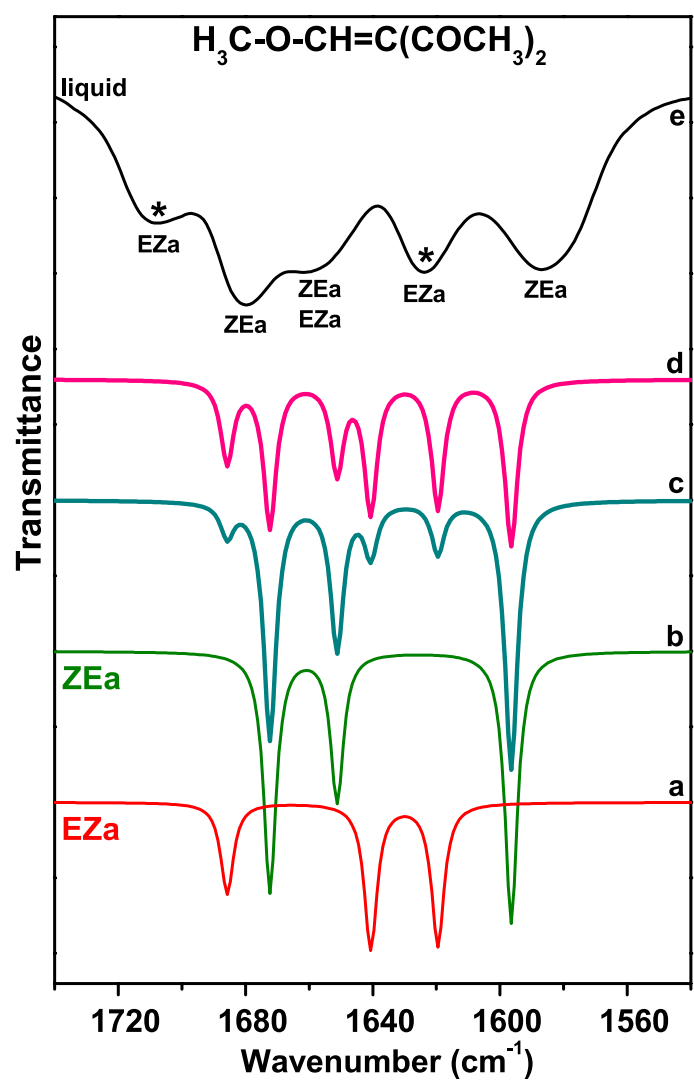

Fig. 14. Calculated IR spectra of individual $Z E a$ and $E Z a$ MMP conformers (curves b and a, respectively) at MP2 level in cc-pVTZ basis set. Calculated IR spectra of MMP with $80 \%$ of $Z E a$ and $20 \%$ of EZa conformers (curve c) and with $50 \%$ of $Z E a$ and $50 \%$ of EZa conformers (curve d). The curves e is an experimental IR spectrum of a neat liquid MMP at room temperature.

To support this conclusion we have calculated IR and Raman band intensities in the region of $\mathrm{C}=\mathrm{O}$ and $\mathrm{C}=\mathrm{C}$ bonds for the mixture of $80 \%$ of $Z E a$ and $20 \%$ of $E Z a$ conformers and $50 \%$ of $Z E a$ and $50 \%$ of EZa conformers (Figs. 13 and 14) and increasing band intensities in more polar surroundings can be explained by the increasing amount of the more polar EZa conformers in the mixture. The calculated IR and Raman band intensities show relatively well agreement with the experimental spectra in this region which cannot be achieved with the opposite assignment.

\section{Conclusion}

The analysis of NMR and vibrational spectra supported by theoretical calculations in vacuum and in the environment of various polarities revealed the existence of two structural forms of MMP. The studied compound exists in the solid state as the 
$Z E a$ conformer and similarly predominate in a less polar environments, e.g. $\mathrm{CCl}_{4}$ or chloroform. In the more polar environments (such as dichloromethane, acetonitrile, DMSO) conformational equilibrium of MMP is visibly shifted towards the EZa conformer and MMP exists in these solutions as a mixture of two $Z E a$ and $E Z a$ conformations. Conformational equilibrium of neat liquid MMP approaches to the conformational equilibrium in the acetonitrile solution.

Such experimental behaviour has been supported also by the solvent effect calculations at $a b$ initio MP2 and DFT B3LYP levels using IEF PGM model. The assignment of normal vibrational modes of MMP based on PED calculations was performed.

Based on the measured vibrational and NMR spectra and quantum-chemical calculations we can conclude that MMP exists as a mixture of both $Z E a$ and $E Z a$ conformers with $Z$ and $E$ orientations of both acetyl groups and with the anti orientation of the methoxy group. This study so extends the spectroscopic and structural information about the push-pull compounds without intramolecular hydrogen bonds.

\section{Acknowledgement \\ This article was created with the support of the Minis- try of Education, Science, Research and Sport of the Slovak Republic within the Research and Development Operational Programme for the project "University Sci- ence Park of STU Bratislava”, ITMS 26240220084, co-funded by the European Regional Development Fund.}

\section{References}

Albrecht R (1977) Prog. Res. 21: 9.

Almenningen A, Gatial A, Grace DSB, Hopf H, Klaeboe P, Lehrich F, Nielsen CJ, Powell DL, Traetteberg M (1988) Acta Chem. Scand. A42: 634.

Becke AD (1988) Phys. Rev. A 38: 3098-3100.

Becke AD (1993) J. Chem. Phys. 98: 5648-5652.

Beech T, Gunde R, Felder P, Günthard H (1985) Spectrochim. Acta 41A: 319.

Bouzard D (1990) Recent Progress in the Chemical Synthesis of Antibiotics; Springer-Verlag: München, p. 249.

Bowles AJ, George WO, Maddams WF (1969) Chem. Soc. B: 810 .

Cadioli B, Gallinella E, Pincelli U (1982) J. Mol. Struct. 78: 215 .

Cahill P, Gold LP, Owen NL (1968) J. Chem. Phys. 48: 1620.

Cook AG (1969) Ed., Enamines: Synthesis, Structure and Reactions; Marcel Dekker: New York.

Cossi M, Barone V, Cammi R, Tomasi J (1996) Chem. Phys. Lett. 255: 327-335. de Smedt J, Vanhouteghem F, van Alsenoy C, Geise HJ, Van der Veken B, Coppens P (1989) J. Mol. Struct. 195: 227.

Diallo AO (1981) Spectrochim. Acta 37A: 529.

Durig JR, Little TS (1981) J. Chem. Phys. 75: 3660.

Dyke SF (1973) The Chemistry of Enamines; Cambridge University Press: London.

Frisch MJ, Trucks GW, Schlegel HB, Scuseria GE, Robb MA, Cheeseman JR, Montgomery JA Jr., Vreven T, Kudin KN, Burant JC, Millam JM, Iyengar SS, Tomasi J, Barone V, Mennucci B, Cossi M, Scalmani G, Rega N, Petersson GA, Nakatsuji H, Hada M, Ehara M, Toyota K, Fukuda R, Hasegawa J, Ishida M, Nakajima T, Honda Y, Kitao O, Nakai H, Klene M, Li X, Knox JE, Hratchian HP, Cross JB, Adamo C, Jaramillo J, Gomperts R, Stratmann RE, Yazyev O, Austin AJ, Cammi R, Pomelli C, Ochterski JW, Ayala PY, Morokuma K, Voth GA, Salvador P, Dannenberg JJ, Zakrzewski VG, Dapprich S, Daniels AD, Strain MC, Farkas O, Malick DK, Rabuck AD, Raghavachari K, Foresman JB, Ortiz JV, Cui Q, Baboul AG, Clifford S, Cioslowski J, Stefanov BB, Liu G, Liashenko A, Piskorz P, Komaromi I, Martin RL, Fox DJ, Keith T, Al-Laham MA, Peng CY, Nanayakkara A, Challacombe M, Gill PMW, Johnson B, Chen W, Wong MW, Gonzalez C, Pople JA, Gaussian 03, Revision A.1, Gaussian, Inc. Pittsburgh PA, 2003.

Frisch MJ, Trucks GW, Schlegel HB, Scuseria GE, Robb MA, Cheeseman JR, Scalmani G, Barone V, Mennucci B, Petersson GA, Nakatsuji H, Caricato M, Li X, Hratchian HP, Izmaylov AF, Bloino J, Zheng G, Sonnenberg JL, Hada M, Ehara M, Toyota K, Fukuda R, Hasegawa J, Ishida M, Nakajima T, Honda Y, Kitao O, Nakai H, Vreven T, Montgomery JA Jr., Peralta JE, Ogliaro F, Bearpark M, Heyd JJ, Brothers E, Kudin KN, Staroverov VN, Kobayashi R, Normand J, Raghavachari K, Rendell A, Burant JC, Iyengar SS, Tomasi J, Cossi M, Rega N, Millam JM, Klene M, Knox JE, Cross JB, Bakken V, Adamo C, Jaramillo J, Gomperts R, Stratmann RE, Yazyev O, Austin AJ, Cammi R, Pomelli C, Ochterski JW, Martin RL, Morokuma K, Zakrzewski VG, Voth GA, Salvador P, Dannenberg JJ, Dapprich S, Daniels AD, Farkas Ö, Foresman JB, Ortiz JV, Cioslowski J, Fox DJ (2009) Gaussian 09, Revision D.01, Gaussian, Inc., Wallingford CT.

Gallinella E, Pincelli U, Cadioli B (1983) J. Mol. Struct. 99: 31.

Gatial A, Sklenák Š, Milata V, Biskupič S, Zalibera L, Salzer R (1997) J. Mol. Struct. 410-411: 435.

Gatial A, Herzog K, Milata V, Zalibera L', Biskupič S, Salzer R (1999) J. Mol. Struct. 482-483: 609.

Gatial A, Milata V, Biskupič S, Pigošová J, Herzog K, Salzer R (2004) Asian Chemistry Letters 8: 169-186.

Gatial A, Juhásová H, Gróf M, Kožíšek J, Milata V, Prónayová N, Matějka P (2011) J. Mol. Struct. 993: 232-242.

Gatial A, Dorotíková S, Plevová K, Milata V, Prónayová N, Matějka P (2015) J. Mol. Struct. 1090: 112-120.

Gróf M, Gatial A, Milata V, Prónayová N, Sümmchen L, Salzer R (2007) J. Mol. Struct. 843: 1-13.

Ignatyev IS, Lazarev AN, Smirnov MB, Alpert ML, Trofimov BA (1981) J. Mol. Struct. 72: 25. 
Lee C, Yang W, Parr RG (1988) Phys. Rev. B 37: $785-789$.

Mennucci B, Tomasi J (1997) J. Chem. Phys. 106: 5151-5158.

Merrick JP, Moran D, Radom L (2007) J. Phys. Chem. A 111: 11683-11700.

Møller C, Plesset MS (1934) Phys. Rev. 46: 618-622.

Oelichmann HJ, Bougeard D, Schrader B (1982) Angew. Chem. Suppl. 1404-1415.
Owen NL, Sheppard N (1964) Trans. Faraday Soc. 60: 634.

Owen NL, Seip HM (1970) Chem. Phys. Lett. 5: 162.

Pyckhout W, Van Nuffel P, Van Alsenoy C, Van den Enden L, Geise HJ (1983) J. Mol. Struct. 102: 333.

Sakakibara M, Inagaki F, Harada I, Shimanouchi T (1976) Bull. Chem. Soc Jpn. 49: 46.

Samdal S, Seip HM (1975) J. Mol. Struct. 28: 193. 